\title{
Growth and Phenological Development of Rough Fescue in Interior British Columbia
}

\author{
DARRYL G. STOUT, ALASTAIR MCLEAN, AND DEE A. QUINTON
}

\begin{abstract}
Growth and phenological development of rough fescue (Festuca scabrella) in interior British Columbia have been documented for a 3-year period. The plants began growing around mid-April and normally ceased growing in late June. Culm growth began in late May and ceased at approximately the time leaf growth ceased. However, leaf and culm elongation ceased before the plants reached their full weight. Rough fescue headed out between May 14 and June 10 and seed shattering occurred between July 13 and July 24. Seed head production per plant was variable from year to year. Fall regrowth occurred in September one year, in October another year, and not at all the other year.
\end{abstract}

Rough fescue (Festuca scabrella) is an important forage species on 1,275,000 ha of grasslands in interior British Columbia, providing up to $10 \%$ of the dry matter yield of the Agropyron-Poa or middle grasslands zone and up to $50 \%$ of the dry matter yield of the Agropyron-Festuca or upper grasslands zone (Tisdale 1947). Rough fescue requires a mesic environment and is therefore most abundant on north and east facing slopes.

As rough fescue is a palatable forage and has an extensive fibrous root system for holding soil, it may be advisable to manage it as the key species when it makes up more than $15 \%$ of the total plant composition (Hodgkinson and Young 1973). Traditionally the middle and upper grasslands of interior British Columbia have been utilized for spring and fall grazing. To help resource managers make the best use of these rough fescue ranges, we havc conducted experiments to document the growth characteristics and the resistance to herbage removal of rough fescue. In this paper we describe the pattern of vegetative and reproductive growth of rough fescue at two sites of interior British Columbia. Possible relationships between growth and environmental parameters are also considered.

\section{Materials and Methods}

\section{Study Areas}

The Hamilton exclosure, fenced in 1931, is located $70 \mathrm{~km}$ south and $26 \mathrm{~km}$ east of Kamloops, B.C., on a $49 \%$ southeasterly slope at an elevation of $1,158 \mathrm{~m}$, and has a Black Chernozemic (Haploboroll) soil with a sandy loam texture. The East Mara exclosure, fenced in 1938 , is located $5 \mathrm{~km}$ west of Kamloops, B.C., on a $20 \%$ northeast slope at $854 \mathrm{~km}$ elevation and has a Black Chernozemic (Haploboroll) soil with a sandy loam texture (McLean and Tisdale 1972).

\footnotetext{
Authors are forage physiologist, range ecologist, and range scientist, Agriculture Canada, Range Research Station, 3015 Ord Road, Kamloops, B.C. Canada, V2B

Authors would like to thank Larry Haupt for his technical help in conducting this experiment and Alice Cogley for helping with data analysis and drafting the figures. Manuscript received May 16, 1979.
} 8A9.

\section{Environmental Measurements}

Rain gauges, and monthly thermographs (model $251 \mathrm{C}$ or $252 \mathrm{C}$ Wilh. Lambrecht Ltd., Gottingen, West Germany) housed in Stevenson screens, were maintained at each site from April 1 to October 31 to monitor rainfall and air temperature. Soil temperature was sampled at 10 and $50 \mathrm{~cm}$ depths, biweekly from April to October and periodically throughout the winter with a battery operated telethermometer (model 43TE, Yellow Springs, Inst. Co. Inc., Yellow Springs, Ohio). Soil samples, from gravimetric moisture content determination, were collected biweekly from April to November at 5 and $25 \mathrm{~cm}$ depths.

\section{Vegetative Growth Measurements}

Each year 30 rough fescue plants at a site were identified with labelled stakes. Yield at each site was determined by harvesting 20 plants to a 5-cm stubble at weekly intervals during the plant growth period. The 20 plants were divided into two groups of 10 plants. Plant tissue from the 10 plants within a group was bulked, dried at $80^{\circ} \mathrm{C}$ and weighed.

In addition to determining the pattern of biomass accumulation, 10 of the 30 plants were randomly chosen to determine the pattern of leaf and culm growth. Average leaf and culm length, measured from ground level, were recorded weekly for each of the 10 plants. When the culm was not visible the length of the outermost leaf sheath was measured, as it would represent the upper limit for the culm length.

\section{Reproductive Growth Measurements}

An additional 30 plants were labelled at each site and used to observe flowering and secd production. The dates of developmental stages (boot, head, flower, and seed) were visually estimated. The boot stage occurred when seed heads were enclosed by the leaf sheath. Early heading was defined to be when $10 \%$ of the heads from all plants had comc out of the boot, and full heading was defined to be when $90 \%$ of the heads were out of the boot. Early flowering was defined to be when $10 \%$ of the heads were flowering and full flowering was defined to be when $90 \%$ of the heads were flowering. At the end of the flowering the anthers discolored and dried up. Seed development was evaluated by estimating the dates when $50 \%$ of the seeds were in the milk, dough, ripe, and shattering stages. To quantitatively evaluate reproductive growth, the number of heads per plant were counted for cach of the 30 plants. Numbers of tillers and basal areas per plant were also determined to evaluate whether or not the number of heads per plant was related to plant size.

\section{Results}

\section{Environmental Conditions}

East Mara is a warmer site than Hamilton (Table 1). September and October air temperatures in 1972 were cooler than during 1971 and 1973 at both sites. May and June average daily air temperatures were lower during 1972 than during 1971 or 1973 at Hamilton. At East Mara, April and May air temperatures were lower in 1972 than in 1971 or 1973. 
Table 1. Air temperature and precipitation at two interior British Columbia sites during 1971, 1972, and 1973.

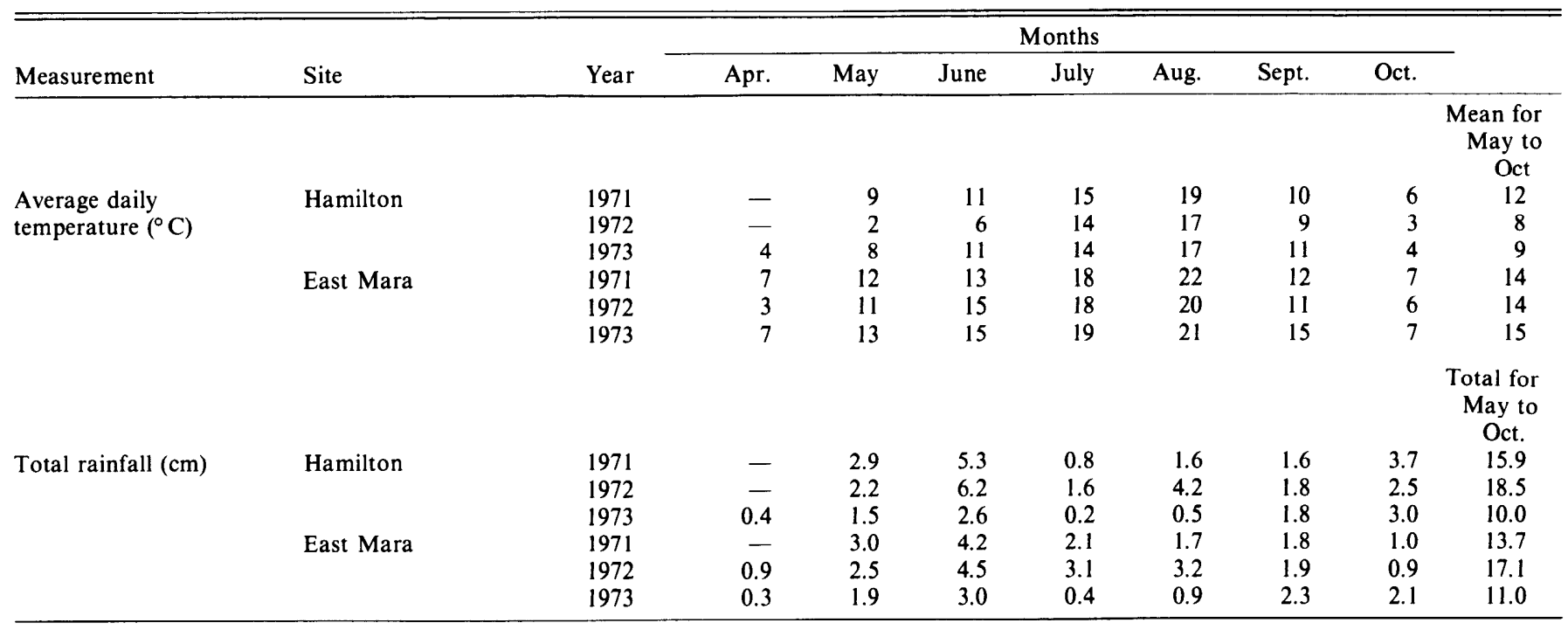

Soil temperatures, at $10 \mathrm{~cm}$, were generally lower at Hamilton than at East Mara (Fig. 1). Soil temperature began to increase at about the same time in April at both sites but it decreased sooner in September at Hamilton. East Mara had higher summer soil temperatures, especially during June, than Hamilton. During winter the Hamilton soil froze at $10 \mathrm{~cm}$ but not at $50 \mathrm{~cm}$, whereas East Mara soil did not freeze at 10 or $50 \mathrm{~cm}(50 \mathrm{~cm}$ data not shown). At East Mara mid-April soil temperature was higher in 1973 than in 1971 or 1972 and September-October soil temperatures were lower in 1972 than in 1971 or 1973.

Total rainfall during May to October was highly variable from year to year at both Hamilton and East Mara (Table 1). Hamilton received more rain than East Mara in 1971 and 1972. May and June rainfall was least in 1973 at both sites.

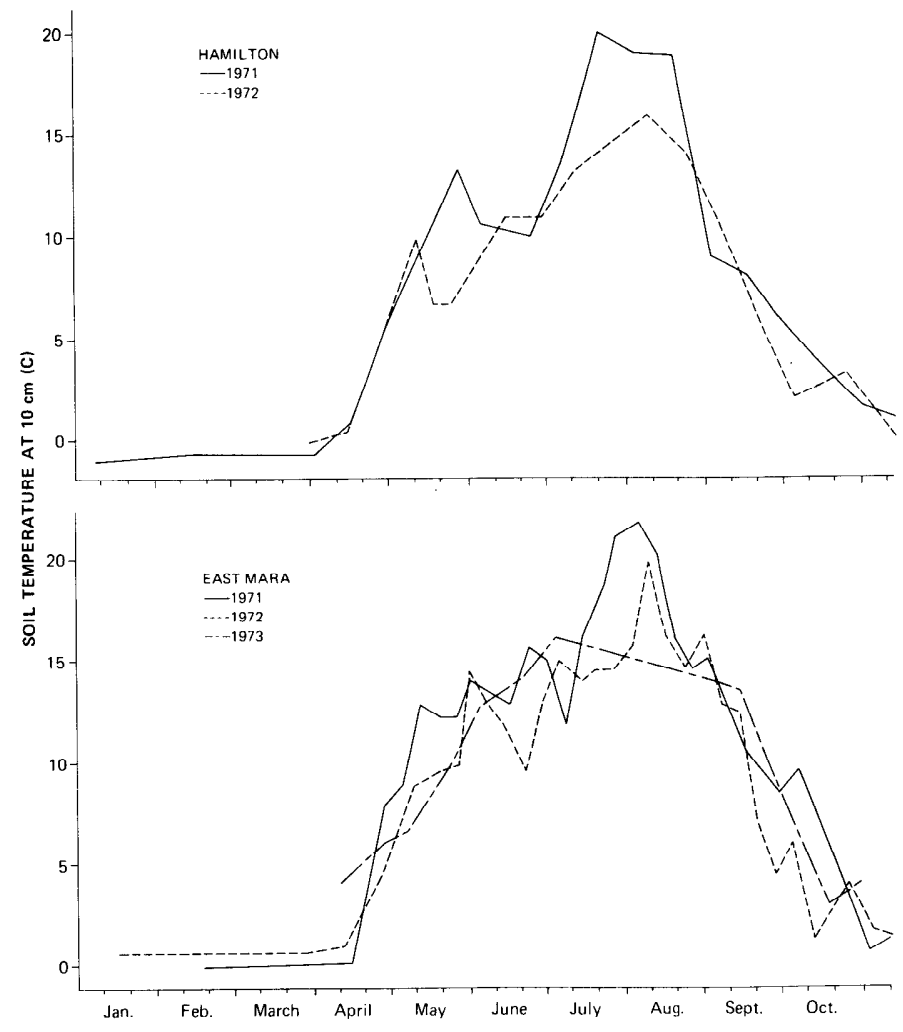

Fig. 1. Soil temperature at a depth of $10 \mathrm{~cm}$ for Hamilton during 1971 and 1972 and for East Mara during 1971, 1972, and 1973.

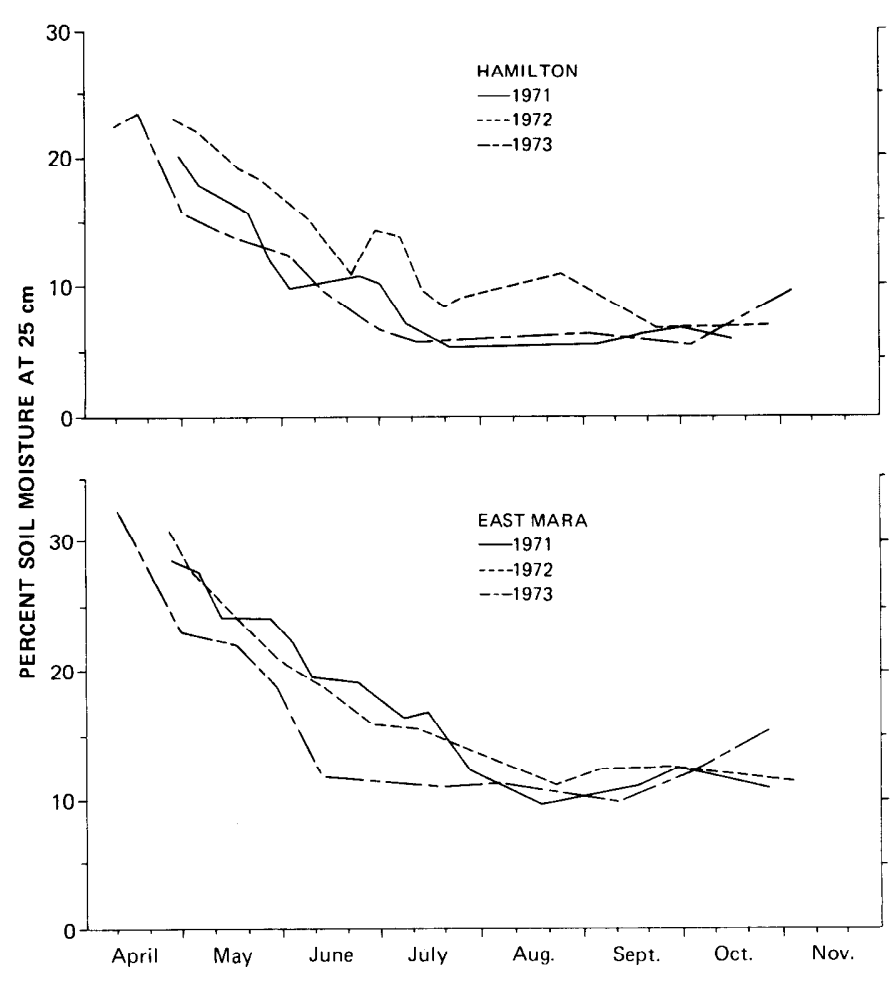

Fig. 2. Soil water content at a depth of $25 \mathrm{~cm}$ for Hamilton and East Mara during 1971, 1972, and 1973.

Soil water content was maximum in the spring (April) and then decreased during the summer (Fig. 2). Soil water content decreased most rapidly from April to June or July and then less rapidly during the rest of the summer and fall. Summer and fall rains were not sufficient to return the soil water content to the early spring values. However, the soil was fully recharged with water following snow melt in April. Soil water content at $5 \mathrm{~cm}$ reflects the rainfall pattern, and so is highly variable during the year (data not shown). Therefore, soil water content at $25 \mathrm{~cm}$ was used for comparison of sites and years. At East Mara and Hamilton, September had a lower soil water content in 1973 than in 1971 or 1972 (Fig. 2); whereas, October soil water content was higher in 1973 than in 1971 or 1972. In general the soil water content was lower in 1973 than in 1971 or 1972 at both sites. The higher soil water content at East Mara likely reflects the soil clay content there and not that it has more available water than Hamilton. 


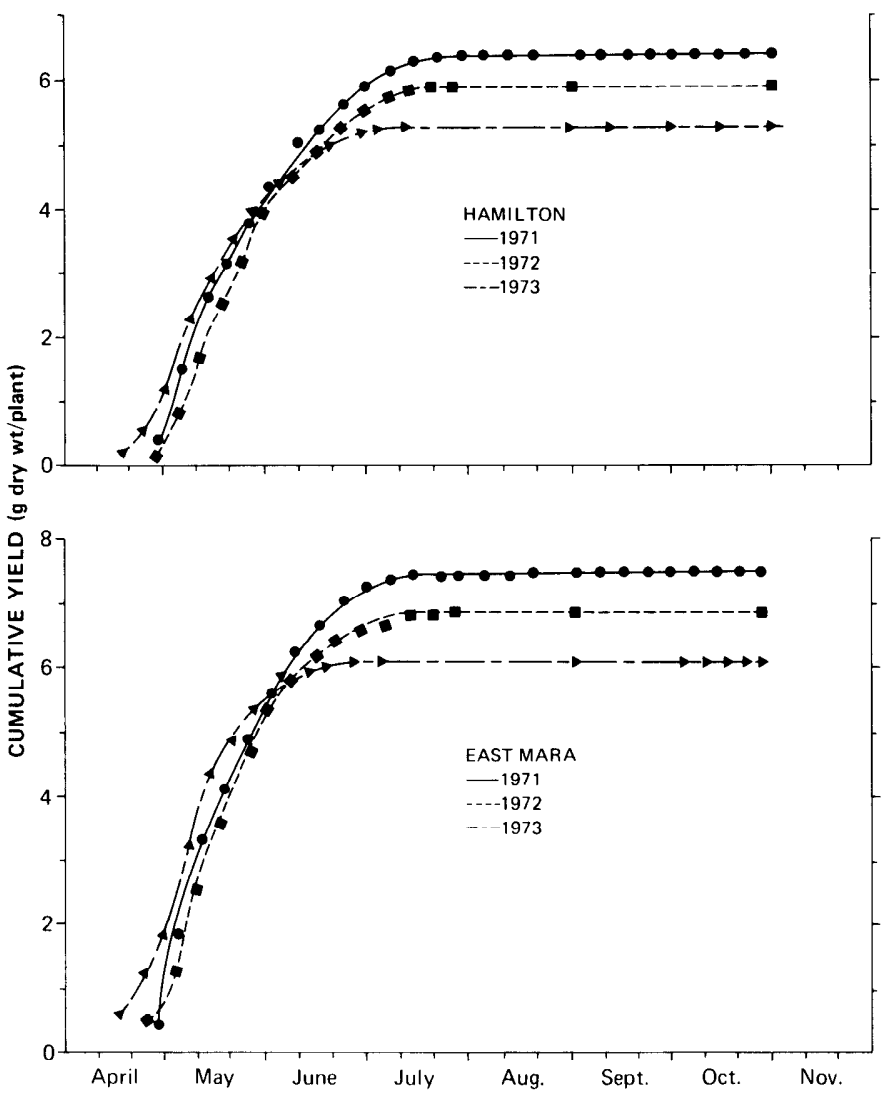

Fig. 3. Cumulative yield at Hamilton and East Mara during 1971, 1972, and 1973. Value are $\overline{\mathrm{X}}$ for two groups of plants each containing 10 plants. $L S D$.05 equalled $0.4 \mathrm{~g}, 1.0 \mathrm{~g}$, and $0.7 \mathrm{~g}$ during 1971, 1972, and 1973, respectively.

\section{Vegetative Growth \\ Weight}

Date of growth initiation in the spring was estimated by extrapolating the growth curves presented in Fig. 3 to zero yield. Visible growth began during the period April 10 to 25 at both sites (Fig. 3). At Hamilton growth was initiated earlier in 1973 than in 1971 or 1972. At East Mara growth occurred earliest in 1973 and latest in 1971. Soil temperature at $10 \mathrm{~cm}$ depth and at the time of growth initiation was $2.9 \pm 0.9^{\circ} \mathrm{C}$ at East Mara and $2.6 \pm 0.1^{\circ} \mathrm{C}$ at Hamilton.

Total yield was greater at East Mara than at Hamilton (Fig. 3). At both sites most growth occurred in 1971 and least growth in 1973. In this experiment, where yield was measured, no fall regrowth occurred.

\section{Leaf Length}

Extrapolating leaf length curves to zero length suggests that leaf growth was initiated between April 1 and 15 (Fig. 4). This period for growth initiation is slightly earlier than the period estimated from yield data. However, it is more difficult to extrapolate the leaf data because the initial portions of the curves are not as linear as was observed for the yield data. Generally, rough fescue initiates growth within 7 to 10 days of April 15 at both study locations. The specific date within this period varies with year. There is no indication that growth initiation occurs at a different time at East Mara than at Hamilton, despite the fact that Hamilton is $304 \mathrm{~m}$ higher in elevation. Ranking of final leaf length for sites and years corresponds to ranking of final yield with the exception that leaf length at East Mara was the same in 1972 and 1973, whereas yield was larger in 1972 than in 1973.

Cessation of leaf length growth was estimated by two methods (Table 2): (1) visual field observations, and (2) measuring leaf length and estimating when the leaves reached their final length by determining on which date each year the average leaf length was

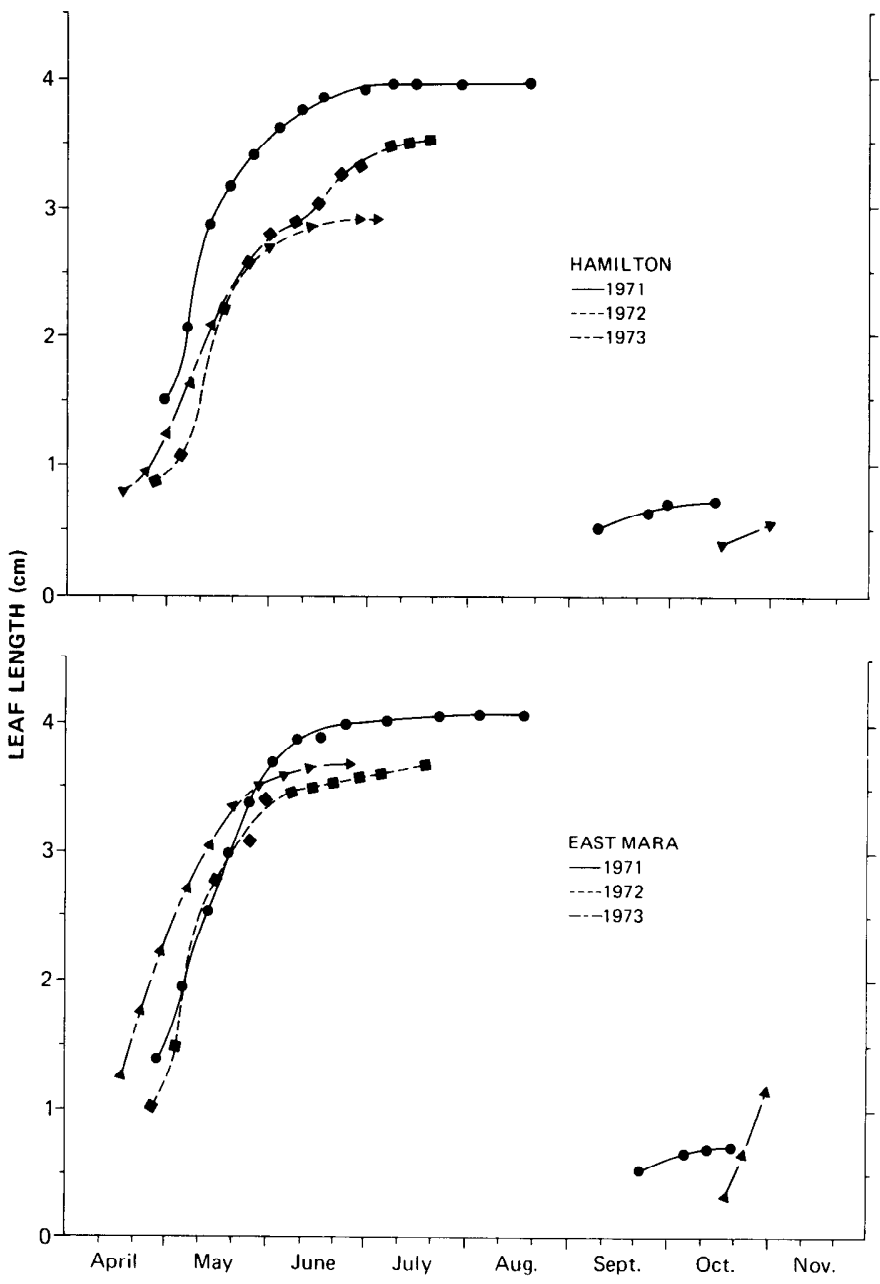

Fig. 4. Growth in leaf length at Hamilton and East Mara during 1971, 1972 and 1973. Values are $\overline{\mathrm{x}}$ for 10 plants. At Hamilton LSD.05 equalled 1.5 $\mathrm{cm}, 1.5 \mathrm{~cm}$, and $1.5 \mathrm{~cm}$ during 1971, 1972, and 1973, respectively, and at East Mara LSD.05 equalled $2.2 \mathrm{~cm}, 1.3 \mathrm{~cm}$, and $1.6 \mathrm{~cm}$ during 1971,1972 , and 1973 , respectively.

significantly different from the final length using Duncan's multiple range test. The measuring technique estimated that leaf growth ceased from 1 to 2 weeks before it was visually observable in the field. Soil water content at $25 \mathrm{~cm}$ when leaf growth ceased was $20 \pm$ $2 \%$ at East Mara and $12 \pm 2 \%$ at Hamilton.

In the leaf length experiment, fall regrowth was observed to occur in 1971 and 1973 at both sites (Fig. 4). In 1971 the regrowth began in September, whereas in 1973 regrowth began in October. This suggests that the lack of regrowth in the yield experiment was due to the clipping.

\section{Culm Length}

At both East Mara and Hamilton culm elongation was detected in 1972 (Fig. 5). The 10 plants used in this experiment were not a sufficiently large enough number to detect the low rates of seed head production which occurred during other years (Tables 2 and 3). Culm elongation in 1972 was initiated between May 26 and 31 at East Mara and May 18 and 25 at Hamilton. The soil water content at $25 \mathrm{~cm}$ was $22 \%$ at East Mara on May 26 and $19 \%$ at Hamilton on May 18.

\section{Reproductive Growth}

Rough fescue reached the full head stage of development during the period May 25 to June 10 at Hamilton, and during the period May 14 to 24 at East Mara (Table 2). Rough fescue was in full flower during the period June 6 to 24 at Hamilton and the period June 5 to 9 at East Mara. Seeds reached the ripe stage during July 5 to 22 at Hamilton and July 3 to 14 at East Mara. Seed shattering occurred during July 5 to 24 at Hamilton and July 3 to 17 at East 


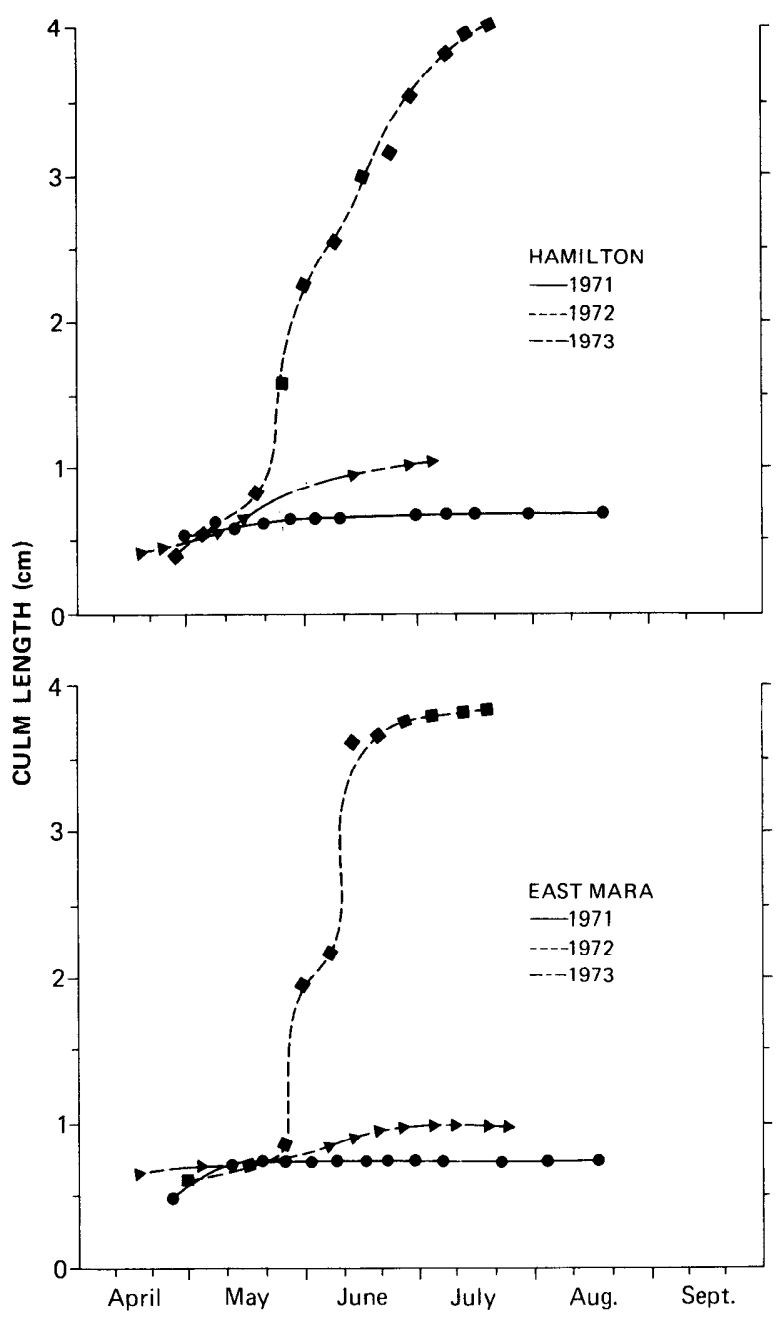

Fig. 5. Growth in culm length at Hamilton and East Mara during 1971, 1972, and 1973. Values are $\overline{\mathrm{x}}$ for 10 plants. At Hamilton ISD.05 equalled $1.4 \mathrm{~cm}, 5.0 \mathrm{~cm}$ and $3.9 \mathrm{~cm}$ during 1971,1972 , and 1973, respectively, and at East Mara LSD.05 equalled $0.4 \mathrm{~cm}, 7.6 \mathrm{~cm}$, and $1.0 \mathrm{~cm}$ during 1971 , 1972 , and 1973, respectively.
Mara. These results demonstrate that heading occurs earlier at East Mara than at Hamilton, but that seed ripeness and shattering occur during the same period at both sites. Therefore, initial development of reproductive organs occurs more slowly at Hamilton than at East Mara but later development of reproductive organs occurs more rapidly at Hamilton than at East Mara.

Number of heads per plant varied dramatically from year to year (Table 3), making it impossible to detect small differences in number of heads per plant. Thus the only statistically significant difference was the high seed head production at Hamilton in 1972. However, the complete lack of head production at both sites in 1974 probably reflects a real difference compared to 1972 and 1973. Number of tillers and basal area per plant indicate that differences in heading were not due to difference in plant size (Table 3 ).

\section{Discussion}

Growth initiation in the spring may be related to soil temperature. Because soil temperatures in the spring were similar at both sites, it was not possible to demonstrate this by comparing sites. However, years can be compared, since soil temperature differed on a particular date from year to year. In 1973 soil temperature at East Mara increased earlier than in 1971 or 1972 (Fig. 1) and growth was initiated earlier (Figs. 3 and 4). Also the estimated soil temperatures $\left(2.9 \pm 0.9\right.$ and $\left.2.6 \pm 0.1^{\circ} \mathrm{C}\right)$ at the time of growth initiation were remarkably similar at the two sites. It has been reported that rough fescue begins growth during May in Alberta when the soil temperature at $20 \mathrm{~cm}$ is $2^{\circ} \mathrm{C}$ (Johnston and MacDonald 1967). Bailey and Anderson (1978) in Alberta observed that rough fescue begins growth soon after snow melt. Growth initiation in the spring would not be limited by insufficient soil water, since soil water content is recharged following snow melt (Fig. 2). At East Mara, April air temperatures were lowest in 1972 (Table 1) yet growth initiation was not dramatically delayed in 1972, especially when compared to 1971 (Figs. 3 and 4). Thus growth initiation appears to be more closely related to soil temperature than to soil water content or to air temperature.

Cessation of rough fescue growth in the summer appears to be related to soil water content. The date for summer growth cessation varied greatly from year to year at both sites (Table 2). However, the soil water content at the time of growth cessation was remarkably similar from year to year at the two sites. Soil water content at the two sites could not be compared since East Mara soil has a higher water holding capacity than Hamilton soil. Yield

Table 2. Phenological development of rough fescue at the two interior British Columbia sites during 1971, 1972 , and 1973.

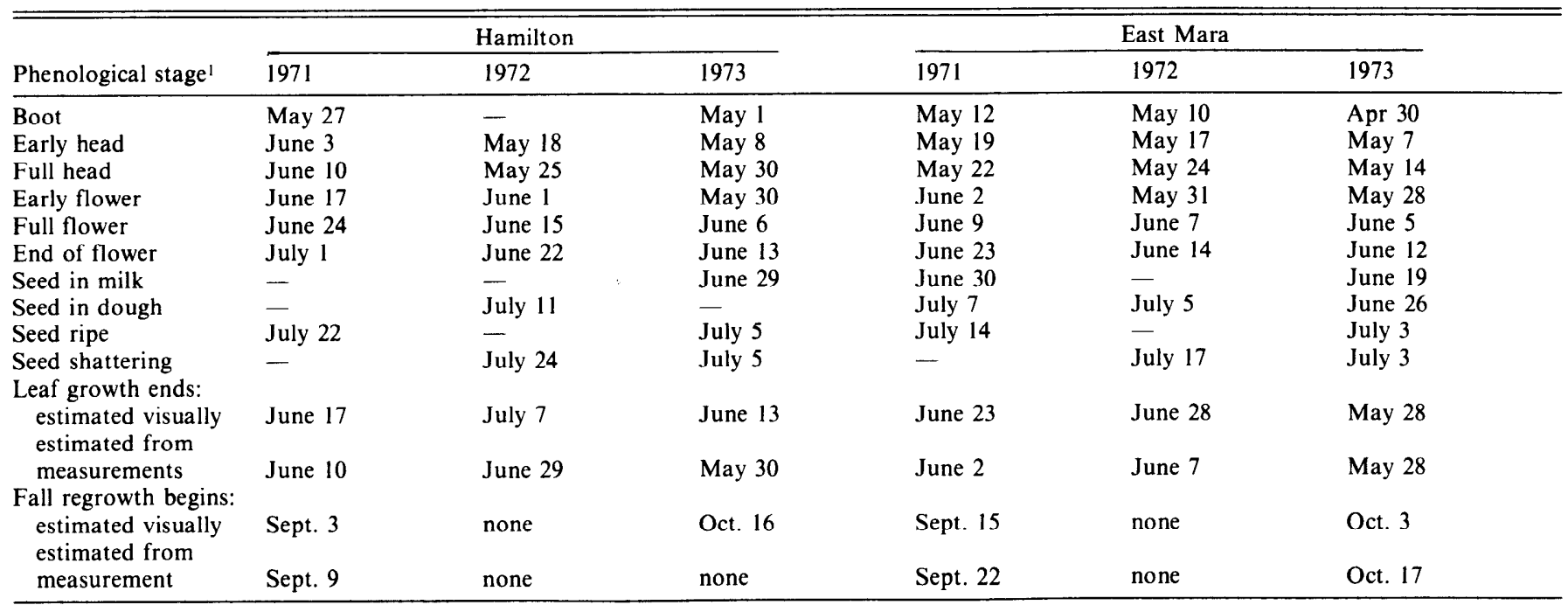

'Early heading was when $10 \%$ of the heads in the boot were pushed out of the boot. Late heading was when $90 \%$ of the heads were out of the boot. Early flowering was when $10 \%$ of the heads were flowering and full flowering was when $90 \%$ of the heads were flowering. The end of leaf growth was estimated visually in the field and was calculated from length measurements using Duncan's multiple range test. 
Table 3. Number of heads and tillers per plant and basal area per plant at the two interior British Columbia sites during 1972, 1973, and 1974.

\begin{tabular}{lcccc}
\hline \hline Site & Year & $\begin{array}{c}\text { Number of } \\
\text { heads/plant }\end{array}$ & $\begin{array}{c}\text { Number of } \\
\text { tillers/plant }\end{array}$ & $\begin{array}{c}\text { Basal } \\
\text { area/plant } \\
\left(\mathrm{cm}^{2}\right)\end{array}$ \\
\hline Hamilton & 1972 & $26.5 a$ & $300 a$ & $84 b$ \\
& 1973 & $3.3 b$ & $241 b$ & $83 b$ \\
East Mara & 1974 & $0.0 b$ & $216 b$ & $80 b$ \\
& 1972 & $1.4 b$ & $321 a$ & $105 a$ \\
& 1973 & $1.5 b$ & $146 c$ & $80 b$ \\
& 1974 & $0.0 b$ & $223 b$ & $100 a$ \\
\hline
\end{tabular}

'Values are $\bar{x}$ for $\mathrm{n}=\mathbf{3 0}$ plants. Different letters indicate significant difference within a column at $P=0.05$ (Duncan's new multiple range test).

continued to increase at low soil water content after leaf growth ceased. This could be expected if growth is being controlled by water supply, since cell expansion is more sensitive to water stress than photosynthesis (Hsiao 1973). Air temperature may also be a factor in growth cessation, since it was quite low at Hamilton during May and June of 1972 and leaf and culm growth continued for a longer than normal period of time at this site in 1972 (Figs. 4 and 5). A lower air temperature would have the effect of decreasing the demand for water. Soil temperature is not high enough at the time of growth cessation to be a limiting factor. In a growthchamber experiment rough fescue plants showed maximum growth at a soil temperature of $18^{\circ} \mathrm{C}$ and showed substantial growth at a soil temperature of $27^{\circ} \mathrm{C}$ (Smoliak and Johnston 1968). Thus rough fescue growth cessation in the summer appears to be mainly controlled by available water.

Rough fescue seed production in Alberta is erratic (Johnston and MacDonald 1967). Erratic seed production might be related to the fact that environmental factors during a rather long time period can affect seed production. For example, seed head initiation occurs in the fall (Johnston and MacDonald 1967), but final seed head development is not completed until the following summer. Seed head production was greatest in 1972 compared to 1973 or 1974 (Table 3). Fall regrowth in 1971 (Fig. 4) showed that fall environmental conditions, at the time when 1972 seed head initiation would be taking place, were favorable at least for vegetative growth. However, 1973 also had fall regrowth (Fig. 4), but no seed heads were produced in 1974 (Table 3). Perhaps it is important that fall regrowth occurred later in 1973 than in 1971. May and June of 1972 were cooler than other years and so the possibility exists that development of seed heads is favored by low temperatures. Unfor- tunately, the explanation for erratic seed head production is not apparent from our recorded environmental data, or from Johnston and MacDonald's (1967) environmental data. This points out the need to monitor as many environmental parameters as possible and the need to record the complete yearly profile of each environmental parameter in order to determine environmental causes for particular growth responses.

In conclusion, the pattern of growth and phenological development of rough fescue in the interior of British Columbia has been documented for a 3-year period. Growth and phenology of rough fescue varies from year to year and site to site. A particular phenological stage only varies within about a 3-week period from year to year. In this experiment, year-to-year variability was approximately equal to site differences. Thus if a range manager appreciates the yearly variability that can occur at a site, the patterns of growth documented in this paper should be useful for making utilization decisions in most parts of interior British Columbia. For example, the probability that one year's rest from grazing would improve the range by allowing natural reseeding is very low. Range grasses are susceptible to grazing during the growth period, and immediately following growth cessation (Stoddart and Smith 1955). Thus the approximate growth period for rough fescue in interior British Columbia, established in this experiment, identifies when the grazing manager should exercise caution. A study designed to determine specific periods during this growth period when rough fescue is especially susceptible to grazing will be reported on in the future.

\section{Literature Cited}

Bailey, A.W., and M.L. Anderson. 1978. Prescribed burning of a FestucaStipa grassland. J. Range Manage. 31:446-449.

Hodgkinson, H.S., and A.E. Young. 1973. Rough fescue (Festuca scabrella Torr.) in Washington. J. Range Manage. 26:25-26.

Hsiao, T.C. 1973. Plant responses to water stress. Ann. Rev. Plant Physiol. 24:519-570.

Johnston. A., and M.D. MacDonald. 1967. Floral initiation and seed production in Festuca scabrella Torr. Can. J. Plant Sci. 47:577-583.

McLean, A., and E.W. Tisdale. 1972. Recovery rate of depleted range sites under protection from grazing. J. Range Manage. 25:178-184.

Smoliak, S., and A. Johnston. 1968. Germination and early growth of grasses at four root-zone temperatures. Can. J. Plant Sci. 48:119-127.

Stoddart, L.A., and A.D. Smith. 1955. Plant physiology in relation to grazing. p. 102-103 In: Range Management. McGraw-Hill, N.Y. 433 p.

Tisdale, E.W. 1947. The grasslands of the southern interior of British Columbia. Ecology 28:346-381.

\section{Membership in the Society for Range Management. . .}

is open to those engaged in or interested in the study, management, or use of range ecosystems and the intelligent use of all range resources

includes research scientists, ranchers, governmental agency administrators and technical personnel, teachers, students, and people from the business community

provides members with two publications-one oriented to research (Journal of Range Management) and the other oriented to practical resource management (Rangelands) offers opportunities for face-to-face exchange of ideas at local. national, and intemational meetings of the Society.

Dues vary according to type of membership and geographical section. For application forms and additional information, contact the:

Executive Secretary

Society for Range Management

2760 West Fifth Avenue

Denver, Colorado 80204

(303) 571-0174 